\title{
The treatment of migraine with propranolol
}

\author{
Ronald B. Weber, M.D., and Oscar M. Reinmuth, M.D.
}

Within recent years a variety of agents have been employed for the symptomatic and prophylactic treatment of the migraine syndrome. The responses to two such agents, ergot derivatives and methysergide, have often been so striking as to have achieved the stature of diagnostic criteria. Despite this fact, a number of migraine sufferers remain without effective therapy because either they are not benefited by these drugs or they cannot risk or tolerate the side effects produced by them.

Recently, Rabkin et al., ${ }^{1}$ Wykes, ${ }^{2}$ and Bekes et $\mathrm{al}^{3}$ independently noted seemingly fortuitous headache improvement in three patients with migraine treated for cardiovascular disease with propranolol, a beta-adrenergic receptor blocker. These observations coupled with our experimental results of propranolol's effects on cerebral blood flow and metabolism ${ }^{4}$ prompted a controlled study on the efficacy of this substance as a modifier of the migraine syndrome.

\section{Method}

The study group consisted of 25 patients, 13 of whom were women. The mean age was 40.6 years, with a range of 19 to 61 years. In every instance these patients were recognized therapeutic management problems, and all met the established criteria for diagnosis of migraine. ${ }^{5} \mathrm{Six}$ patients failed to complete the study for reasons unrelated to the trail drug per se, so that 19 patients comprised the final study group. Thirteen of these patients had headache with no focal neurological distur-

\footnotetext{
* Both drugs were provided by Ayerst Laboratories.
}

bance, and 6 suffered from headache preceded or accompanied by neurological phenomena.

All patients had normal neurological examinations and were free of disorders that could be aggravated by beta-adrenergic receptor blockade, namely, cardiac disease, asthma, and diabetes mellitus.

A randomized double-blind study technique with a single crossover of propranolol (Inderal(i) , 20-mg. tablets, and placebo (mannitol)* was employed. The patients were instructed to take a single tablet four times a day. They were not told that they would receive a placebo for one-half of the study period. The duration of the study was six months per patient. Each patient was seen at four-week intervals to assess the frequency and severity of headaches and drug side effects. Blood pressure and heart rate were also recorded at these visits. No restriction was placed on the use of symptomatic medication (salicylates, ergotamine, etc.) for headache during the study. Prophylactic use of ergotamine compounds and methysergide was prohibited, however.

\section{Results}

Table 1 defines the symptomatic response to Inderal. The criteria for improvement of symptoms were based upon frequency and

From the Department of Neurology, University of Miami School of Medicine, Miami

Read at the twenty-third annual meeting of the American Academy of Neurology, New York City, April 30, 1971 Received for publication April 22, 1971

Dr. Weber's address is Department of Neurology, George Washington University Medical Center, 2150 Pennsylvania Avenue, N.W., Washington, D.C. 20037. 
TABLE 1

DEFINITIONS OF SYMPTOMATIC RESPONSES TO PROPRANOLOL AND PLACEBO

EXCELLENT
ALSENT ARTER FIRST WEEK OF STUDY
MOODAIINE

FAIR MINIMAL SYMPTOMATIC IMPROVEMENT

NO EFFECT

duration of headaches, type and amount of symptomatic medication required for relief, and subjective description of headaches. Analyzing each three-month time period individually in response to Inderal is conspicuous.

First three months. Eight patients received Inderal and 11, placebo. Five of the $8(63 \%)$ patients receiving Inderal had a good or excellent response, 2 had minimal improvement, and 1 was unaffected. Ten of the 11 (91\%) of those receiving placebo had no effect. One patient had a fair response. This comparative effect is significant $(p<0.002$ ).

Second three months. In the group of 8 patients who received Inderal first, 6, or 75\%, had no effect from placebo, whereas 2 who had done well on Inderal continued to do as well on placebo. In the group receiving Inderal in the second half of the study, 10 of the 11 , or $91 \%$, had excellent or good responses. One patient had no effect from either drug.

During this second three-month period the response to Inderal again was significantly better than that to placebo $(p<0.02)$.

Analyzing all patients irrespective of sequence of drug administration, 15 of $19(79 \%)$ responded better to Inderal than to placebo. Four of the $19(21 \%)$ responded similarly to Inderal and placebo. Two of these patients had no effect from either substance. One patient had a good and 1 had an excellent response to placebo (Table 2). Both of these beneficial reactions to placebo followed favorable responses to Inderal. This could represent placebo effect or a carry-over effect of Inderal.

Classic vs, common migraine. Good or excellent responses to Inderal were obtained in $77 \%$ of patients with common migraine and in $83 \%$ of those with classic migraine. It is noteworthy that in 2 patients with classic migraine, Inderal completely eliminated headache while neurological prodromes continued in an attenuated form.

Male vs. female response. Seven of 9 men, or $77 \%$, had good or excellent response to Inderal, while 8 of 10 women similarly benefited.

\section{Side effects}

A single patient complained of abdominal cramps and diarrhea, which were easily controlled by anticholinergics.

Side effects are variable but rare. In Steven's series of 1,500 cardiac patients treated with oral propranolol, light-headedness, drowsiness, nausea, and diarrhea were the most frequently encountered side effects. ${ }^{6}$ However, no side effects occurred in $98.5 \%$ of his patients.

\section{Discussion}

The pathogenesis of migraine remains enigmatic. The roles of vasoactive amines and their metabolism, imbalance of vasoconstrictorvasodilation mechanisms, and precapillary shunting have not been satisfactorily explained. Thus, any explanation of the efficacy of propranolol in the prophylactic treatment of migraine would at best be speculative.

The pharmacology of propranolol deserves

TABLE 2

RELATTVE RESPONSES OF 19 PATIENTS TO PROPRANOLOL AND PLACEBO

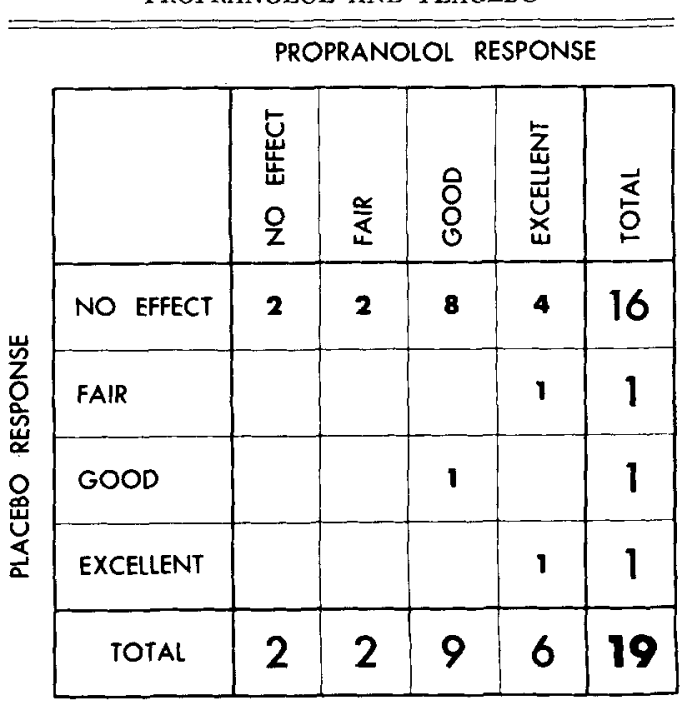


TABLE 3

SUMMARY OF SALIENT PHARMACOLOGIC PROPERTIES OF PROPRANOLOL

DECREASES VASODILATOR RECEPTIVITY $\longrightarrow$ INCREASED VASCULAR RESISTANCE

DECREASES CEREBRAL $O_{2}$ UTILIZATION

DECREASES CARDIAC OUTPUT AND BLOOD PRESSURE BY DECREASING VENTRICULAR CONTRACTILITY

INCREASES GLYCOGEN IN BRAIN AND MUSCLE BY REDUCING PHOSPHORYLASE ACTIVITY

REDUCES HEART RATE

a. DECREASED ACTIVITY OF S-A NODE

b. DECREASED CONDUCTION THROUGH A.V NODE

LOCAL ANESTHETIC (potency of Lidocaine)

INHIBITS PARKINSONIAN TREMOR

\pm ANTICONVULSANT

comment. The major sites of beta-adrenergic activity are the conducting system of the heart and the smooth muscle of the arteries, veins, and bronchioles.7,8 Catecholamine-mediated phosphorylase activation also enhances glycogenolysis. $^{9-12}$ Hence, the potential complications of beta blockade are precipitation or potentiation of heart failure, asthma, and hypoglycemia. Fortunately, these hazards are confined to patients with these special proclivities and can be obviated by careful patient selection. Table 3 summarizes the major pharmacologic effects of propranolol.

Various mechanisms may be important in explaining the benefical influence of propranolol upon migraine. The most evident is blockade of vasodilator receptors in adrenergically innervated vessels. ${ }^{13-17}$ This putatively would influence the extracranial vessels' contribution to the headache phase ${ }^{18,19}$ by creating a vasoconstrictor bias and preventing reactive vasodilation.

Our unpublished observations of reduced cerebral oxygen consumption in dogs after propranolol administration suggest an effect on intracranial vessels secondary to alteration of cerebral metabolism. ${ }^{4}$ Others ${ }^{20,21}$ have demonstrated that this independent effect of propranolol is probably due to inhibition of beta-adrenergically controlled cerebral glyco- genolysis and glycolysis. ${ }^{22}$ The resultant effect would be removal of a metabolic vasodilator influence on the smallest vessels at the tissue level. This net vasoconstrictor effect should be maximal on the tissue vessels that probably do not serve as a source of pain. Theoretically we might predict that the neurological prodromes of migraine would be made worse, but this was not true in our patients. Equally vexing is the ability of propranolol to block the vasoconstrictive effects of barium chloride topically applied to pial vessels. ${ }^{23}$ This pradoxical antispasmodic effect further reflects lack of beta-adrenergic specificity of propranolol as recognized in other systems. ${ }^{24-27}$

We conclude that propranolol is an effective and safe agent for prophylaxis in complicated and repetitive migraine. Further experience will determine whether propranolol should assume a position of first-choice therapy.

\section{Summary}

Nineteen patients with refractory migraine were treated with prophylactic propranolol, 80 mg. per day, and placebo in a six-month double-blind study. Fifteen of 19 patients responded better to propranolol than to placebo, $2(10.5 \%)$ were improved by active drug and placebo, and the remaining 2 were unresponsive to both substances.

The authors conclude that propranolol prophylaxis is a safe and effective therapy for migraine. Familiarity with the pharmacologic effects of propranolol and careful selection of patients are essential.

The exact mechanisms of action of propranolol in migraine are unknown. However, the authors speculate on the possible modes of action in view of the current understanding of the properties of propranolol.

\section{ACKNOWLEDGMENTS}

The authors wish to thank Dr. Jacqueline Trent and Mr. Robert Kyle of Ayerst Laboratories for their assistance in this study.

\section{REFERENCES}

1. Rabkin R, Stables DP, Levin NW, et al: Propranolol and prophylaxis of angina pectoris. Amer $\mathbf{J}$ Cardiol $18: 370,1966$

2. Wykes $P$ : The treatment of angina pectoris with coexisting migraine. Practitioner 200:702, 1968

3. Bekes M, Matos $L_{3}$ Rausch J, et al: Treatment of migraine with propranolol. Lancet 2:980, 1968

4. Fujishima M, Reinmuth OM: Unpublished observations.

5. Classification of headache. JAMA 179:717, 1962

6. Steven SA: Unwanted effects of propranolol. Amer J Cardiol 18:463, 1966 
7. Ahlquist RP: Study of the adrenotropic receptors. Amer I Physiol 153:586, 1948 8. Furchgott RF: The pharmacological differentiation of
adrenergic receptors. Ann NY Acad Sci 139:553, 1967

9. Sutherland EW, Rall TW: The relation of adenosine3,5 -phosphate and phosphorylase to the actions of catecholamines and other hormones. Pharmacol Rev 12:265,1960

10. Ali HI, Antonio A, Haugaard N; The action of sympathomimetic amines and adrenergic blocking agents on tissue phosphorylase activity. J Pharmacol Exp Ther $145: 142,1964$

11. Haugaard N, Hess ME: Actions of autonomic drugs on phosphorylase activity and function. Pharmacol Rev $17: 27,1965$

12. Mayer SE, Williams BJ, Smith JM: Adrenergic mechanisms in cardiac glycogen metabolism. Ann NY Acad Sci 139:686, 1967

13. Nelson E, Rennels $M$ : Innervation of intracranial arteries. Brain $93: 475,1970$

14. Shanks RG: The pharmacology of beta sympathetic blockade. Amer J Cardiol 18:308, 1966

15. Sowton E, Hamer J: Hemodynamic changes after betaadrenergic blockade. Amer J Cardiol 18:317, 1966

16. Brick I, Glover WE, Hutchison $\mathrm{KJ}$, et al: Effects of propranolol on peripheral vessels in man. Amer $J$ Cardiol 18:329, 1966

17. Charbon GA, Reneman RS: The effects of beta-receptor agonists and antagonists on regional blood flow. Europ J Pharmacol $9: 21,1970$
18. Wolff HG, Tunis MM: Analysis of cranial artery pressure pulse waves in patients with vascular headache of the migraine type. Trans Ass Amer Physicians $65: 240,1952$

19. Wolff HG: Headache and Other Head Pain. New York, Oxford University Press, 1963

20. Estler CJ, Ammon HPT: The influence of the betasympathicolytic agent propranolol on glycogenolysis and glyolysis in muscle, brain and liver of white mice. and glyolysis in muscle, brain and

21. Estler CI, Ammon HPT: Antagonistic effects of dopa and propranolol on brain glycogen. J Pharm Pharmacol 22:146, 1970

22. Laubie $M$, Drouillat $M$ : Action de I'isoprotérénol sur l'hémodynamique et le métabolisme cérébral du chien. Arch Int Pharmacodyn 170:93, 1967

23. Rosenblum WZ: Cerebral arteriolar spasn inhibited by beta-adrenergic blocking agents. Arch Neurol (Chicago) $21: 296,1969$

24. Usubiaga JE: Neuromuscular effects of beta-adrenergic blockers and their interaction with skeletal muscle relaxants. Anesthesiology 29:484, 1968

25. Vaughn Williams EM: Central nervous system effects of beta-adrenergic blocking drugs. Ann NY Acad Sci $139: 808,1967$

26. Leszkovszky G, Tardos L: Some effects of propranolol on the central nervous system. J Pharm Pharmacol on the centra

27. Whitsitt LS, Lucchesi BR: Effects of propranolol and its stereoisomers upon coronary vascular resistance. Circ Res $21: 305,1967$ 


\section{Neurology}

\section{The treatment of migraine with propranolol}

Ronald B. Weber and Oscar M. Reinmuth

Neurology 1972;22;366

DOI 10.1212/WNL.22.4.366

\section{This information is current as of April 1, 1972}

\section{Updated Information \& \\ Services}

Permissions \& Licensing

Reprints including high resolution figures, can be found at:

http://n.neurology.org/content/22/4/366.citation.full

Information about reproducing this article in parts (figures,tables) or in its entirety can be found online at:

http://www.neurology.org/about/about_the_journal\#permissions

Information about ordering reprints can be found online:

http://n.neurology.org/subscribers/advertise

Neurology $®$ is the official journal of the American Academy of Neurology. Published continuously since 1951, it is now a weekly with 48 issues per year. Copyright (C) 1997 by the American Academy of Neurology. All rights reserved. Print ISSN: 0028-3878. Online ISSN: 1526-632X.

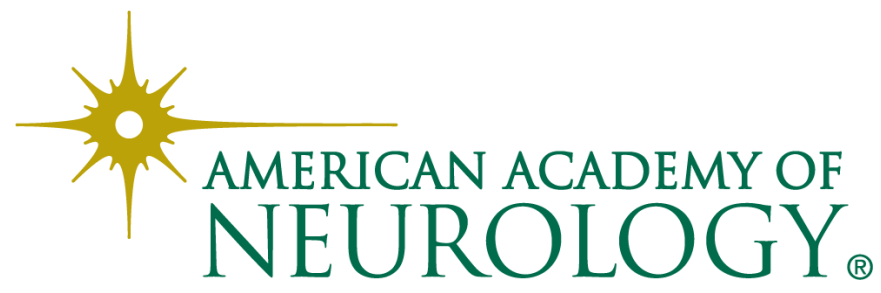

